\title{
"Perspectives for non-primary export development in Russia and measures of its tax incentives"
}

\begin{tabular}{|c|c|}
\hline AUTHORS & $\begin{array}{l}\text { Elena Dedkova } \text { http://orcid.org/0000-0003-3392-2952 } \\
\mathbb{R} \text { http://www.researcherid.com/rid/J-4234-2017 } \\
\text { Aleksandr Gudkov D http://orcid.org/0000-0002-4006-4522 } \\
\mathbb{R} \text { http://www.researcherid.com/rid/H-7717-2016 } \\
\text { Kristina Dudina } \mathbb{~ h t t p : / / o r c i d . o r g / 0 0 0 0 - 0 0 0 1 - 5 1 1 3 - 7 0 2 1 ~} \\
\mathbb{R} \text { http://www.researcherid.com/rid/A-6764-2016 }\end{array}$ \\
\hline ARTICLE INFO & $\begin{array}{l}\text { Elena Dedkova, Aleksandr Gudkov and Kristina Dudina (2018). Perspectives for } \\
\text { non-primary export development in Russia and measures of its tax incentives. } \\
\text { Problems and Perspectives in Management, 16(2), 78-89. } \\
\text { doi:10.21511/ppm.16(2).2018.08 }\end{array}$ \\
\hline DOI & http://dx.doi.org/10.21511/ppm.16(2).2018.08 \\
\hline RELEASED ON & Thursday, 03 May 2018 \\
\hline RECEIVED ON & Wednesday, 21 February 2018 \\
\hline ACCEPTED ON & Wednesday, 18 April 2018 \\
\hline LICENSE & $\begin{array}{l}(c) E Y \text { EY } \\
\text { This work is licensed under a Creative Commons Attribution } 4.0 \text { International } \\
\text { License }\end{array}$ \\
\hline JOURNAL & "Problems and Perspectives in Management" \\
\hline ISSN PRINT & $1727-7051$ \\
\hline ISSN ONLINE & $1810-5467$ \\
\hline PUBLISHER & LLC "Consulting Publishing Company "Business Perspectives" \\
\hline FOUNDER & LLC "Consulting Publishing Company "Business Perspectives" \\
\hline
\end{tabular}

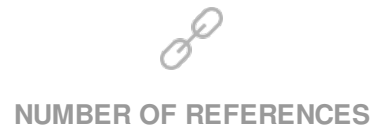

30
NUMBER OF FIGURES

3
NUMBER OF TABLES

2

(C) The author(s) 2022. This publication is an open access article. 


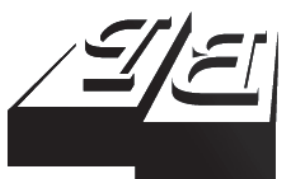

BUSINESS PERSPECTIVES

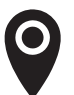

LLC "CPC "Business Perspectives" Hryhorii Skovoroda lane, 10, Sumy, 40022, Ukraine

www.businessperspectives.org

Received on: $21^{\text {st }}$ of February, 2018 Accepted on: $18^{\text {th }}$ of April, 2018

(C) Elena Dedkova, Aleksandr Gudkov, Kristina Dudina, 2018

Elena Dedkova, Ph.D. in Economics, Associate Professor of the Department of Economy, Finance and Accounting, Orel State University, Russia.

Aleksandr Gudkov, Ph.D. in Economics, Associate Professor of the Department of Economy, Finance and Accounting, Orel State University, Russia.

Kristina Dudina, Ph.D. in Economics, Orel State University, Russia.

\section{(ㄷ)(ㄱ)}

This is an Open Access article, distributed under the terms of the Creative Commons Attribution 4.0 International license, which permits unrestricted re-use, distribution, and reproduction in any medium, provided the original work is properly cited.

\title{
PERSPECTIVES FOR NON-PRIMARY EXPORT DEVELOPMENT IN RUSSIA AND MEASURES OF ITS TAX INCENTIVES
}

\begin{abstract}
Non-primary export is one of the most promising areas for the development of Russian foreign economic activity. However, the significant influence of geopolitical problems and underdeveloped internal mechanisms of statutory regulation, state support and stimulation of non-primary exports in Russia do not allow to use all available potential in this regard. As such, the problems of non-primary export development in Russia are being actualized with a view to ensuring a positive influence of this kind of foreign economic activity both on the welfare of the state as a whole and on strengthening its positions in world markets.
\end{abstract}

The purpose of the article is to consider the specifics of non-primary export development in Russia and to propose measures to stimulate its growth.

The object of the study is the existing system of non-primary export in Russia with its inherent features and operating principles.

The research methodology is as follows: scientific search, generalization, systematization, analysis, graphical construction, modeling, formalization, and forecasting.

The key research results consist in the systematization of information on Russia's promising non-primary export industries, the study of the current system of state support for export, the identification of problematic aspects and the search for solutions, and the development and justification of mechanisms for tax incentives for non-primary export, including due to the proposed division of enterprises into target groups depending on the volume of income from their foreign economic activities.

The practical value of the results obtained is that they can be used at the macro level by introducing amendments to the regulatory and legislative acts of the Russian Federation on export regulation in accordance with the results of the grant of the President of the Russian Federation for stimulating and supporting non-primary export.

\section{Keywords economy, export, non-primary export, taxes, tax incentives, export policy, economy growth}

\section{JEL Classification $\quad$ H25, O19}

\section{INTRODUCTION}

The current stage in the development of the world economy is characterized by the shift of many countries away from financial dependence on the sale of raw materials (mainly hydrocarbons) towards increasing the export of renewable, labor-intensive, technological products, as well as demanded services. Export is one of the most promising and profitable sources of the budget, and non-primary export, as a priority area of foreign economic activity, increases its share in the overall export performance and in many countries of the world it is more than $50 \%$.

In this aspect, the search for effective measures for the non-primary export development in Russia as an important direction ensuring GDP growth among other things becomes relevant. The development 
of non-primary export in Russia is attributed to the relative complexity of doing business, the state control rigidity, fragmentation and the large volume of regulatory legal acts, the lack of effective incentive measures for participants in this market, mainly economic and tax, which often makes this area unprofitable in terms of investment and obtaining a stable and high entrepreneurial income.

In this regard, there is an objective need to address the following problem - the formation of unified approaches to differentiating non-primary export enterprises with the aim of their state support and tax incentives.

\section{RECENT RESEARCH AND PUBLICATIONS ANALYSIS}

An analysis of the literature on export development showed that the bulk of it is devoted to research in the field of export and import of raw materials: natural resources such as coal, oil, gas, etc. The issues of non-primary export are rarely addressed and are severely fragmented, which emphasizes the need for a general study in this area for comprehensive understanding of the issue - the prospects for the non-primary export development in Russia and the possibilities for promoting it.

Rangasamy holds that economic policy has always played an important role to export production in the overall growth process. The author attempts to ascertain whether the emphasis on export production is justified (Rangasamy, 2009). Laumas (1982) applies a varying-parameter regression model and concludes that the possibility of attaining higher rates of savings from the export sector is valid for primary goods exporting countries, but cannot be generalized to include non-primary goods exporting developed and less developed countries. Brown (2018) proposes a new analysis of the market and welfare effects of export subsidies. Kalafsky believes that the relationship between exports and economic growth is a paradigmatic element of modern economic growth policy, despite the absence of strong evidence of a connection. The article concludes that export dynamics should be viewed increasingly from an urban frame, with particular emphasis on the production of globally consumed knowledge products and advanced manufacturing. Moreover, export policy should be directed toward the individual strengths of urban regions (Kalafsky et al., 2017). Kiendrebeogo's main results show that financial constraints reduce export participation of firms, while financial liquidity improves it. Moreover, financial constraints have a negative impact on alternative measures of export activity, namely, export intensity and the time the firm takes before starting to export (Kiendrebeogo et al., 2017). Fujii believes that substantial fraction of international trade is facilitated by wholesalers who enable manufacturers to indirectly export their products to foreign markets (Fujii et al., 2017). Krammer advances a two-stage theoretical model which contends that the export performance of emerging economy firms (EEFs) will depend both upon their firm-specific capabilities and their home institutional environments. Specifically, they argue that EEFs will be more likely to export when facing more uncertainty at home from greater political instability, substantial informal competition, and high corruption (Krammer et al., 2018).

Hjerpe explored outdoor recreation as a sustainable export industry (Hjerpe, 2018). Suri discusses the relationship among exports, outward FDI and total sales of pharmaceutical industry. It was found that in the context of Indian pharmaceutical sector, exports cause outward FDI and in turn previous year's outward FDI has a direct impact on current year's exports (Suri et al., 2017). Kadochnikov assesses the impact of FDI spillovers on the propensity to export for Russian firms in manufacturing industries. Estimates show that spillovers were most significant in 2015 when a positive effect of currency devaluation was observed (Kadochnikov et al., 2017). Kaliappan regarded services trade as a new source of income, especially for developing countries. The findings imply that the developing countries should focus on formulating appropriate policy measures to enhance the performance of services sector and service export to stimulate the economic growth (Kaliappan et al., 2017). The paper by Yusupova deals with the research devoted to characteristics of high tech business development in Russia. The relationship between in- 
novation activity indicators and export potential is determined (Yusupova et al., 2017). Tashlykov considers issues related to the export of educational services in the modern world. Attention is paid to the analysis of state regulation of support for export of services of Moscow educational institutions, since this experience can be transmitted to other regions of Russia (Tashlykov, 2007).

Dumnaya considers the possibilities of the Russian economy's shift from the raw material export orientations, because this remains an insoluble problem that turns into a significant gap for Russia with world leaders, increased raw material dependence, unfavorable terms of trade, etc. Much attention is paid to the role of state support for medium-sized companies, taking into account foreign experience in solving such problems (Dumnaya et al., 2015). Rementsov considers the main directions of educational services export and the issues of expediency of training foreign citizens from the position of the state and the university. The author analyzes the driving factors causing the desire of foreign citizens to study at Russian universities and the specifics of the training process for foreign citizens, including joint educational programs, to maintain competitiveness at the world level (Rementsov, 2015). Susanian considers export to be the most important factor in the Russian economy development and therefore determines the need for state support for Russian export of high conversion products. However, the fragmented application of various measures to stimulate export activities that are not united by a single strategic plan cannot give an appropriate idea of their effectiveness and the appropriateness of further implementation. An integrated approach is proposed in the use of numerous traditional and non-traditional forms of export support (Susanian, 2010). Shuyskiy comes to the conclusion that the export specialization of Russia in many respects resembles the least developed countries, since mainly fuel and raw materials are exported. The analysis reveals that in the last decade, the commodity structure of Russian exports has deteriorated even more, so significant effective measures are needed to improve the system of exports support and diversification (Shuyskiy, 2015).

Of particular interest to Russia may be the study of the experience of countries similar in development. Thus, Ünal while studying the Turkish econ- omy came to the conclusion that economy was able to develop more consistent export growth by forced institutional changes (Ünal, 2018). Lianling calculated domestic value added (DVA) in China's exports for 2002, 2007, and 2010. The increase in DVA generated by exports is due mainly to the expansion of export volume. The most effective way to increase exported DVA sustainably is to expand fabrication effects (Lianling et al., 2017).

Based on the analysis of various studies on export promotion in the world, one can make an unambiguous conclusion that the use of tax incentives for this industry is rarely and superficially addressed. Usually, the authors agree with the view that taxation is an effective instrument of influence, but they do not work out specific elements of this impact, taking into account changes in the state of the country's economy.

The purpose of the article is to consider the specifics of the Russia's non-primary export development and to propose specific measures to ensure a substantial positive growth in the total export income, support for Russian producers of goods, works and services, and strengthen their position in the world non-primary market.

\section{METHODOLOGY}

The authors used the following methods while conducting the study: synthesis, generalization, theoretical modeling, analysis, graphical construction, formalization, forecasting. The positions of the research are also argued through private scientific methods of research (formal, comparative, functional, concretization, etc.). Official statistics and analytical reports of the Russian federal authorities served as the information basis of the study.

\section{KEY RESEARCH RESULTS}

The development of technologies and the gradual depletion of resources, the reduction in the demand for hydrocarbon raw materials and the transition to new sources of energy require an early revision of the state's export policy with the transition to non-primary sectors and complete shift away from raw dependence. 
Figure 1 presents the author's opinion about the main existing and promising industries that manufacture products, provide services that are exported or can be exported.

The dependence of the Russian economy on incomes from export of gas, oil and other raw materials should be also leveled at the expense of reorientation to non-primary exports.
Especially given the fact that the current situation on the world political arena and economic platforms today more than ever contributes to this (Dedkova, 2017).

In 2014, the share of Russia's non-primary exports was $51.5 \%$, for the first time it exceeded the share of raw materials exports (goods and services at about USD 500 billion were sold abroad).

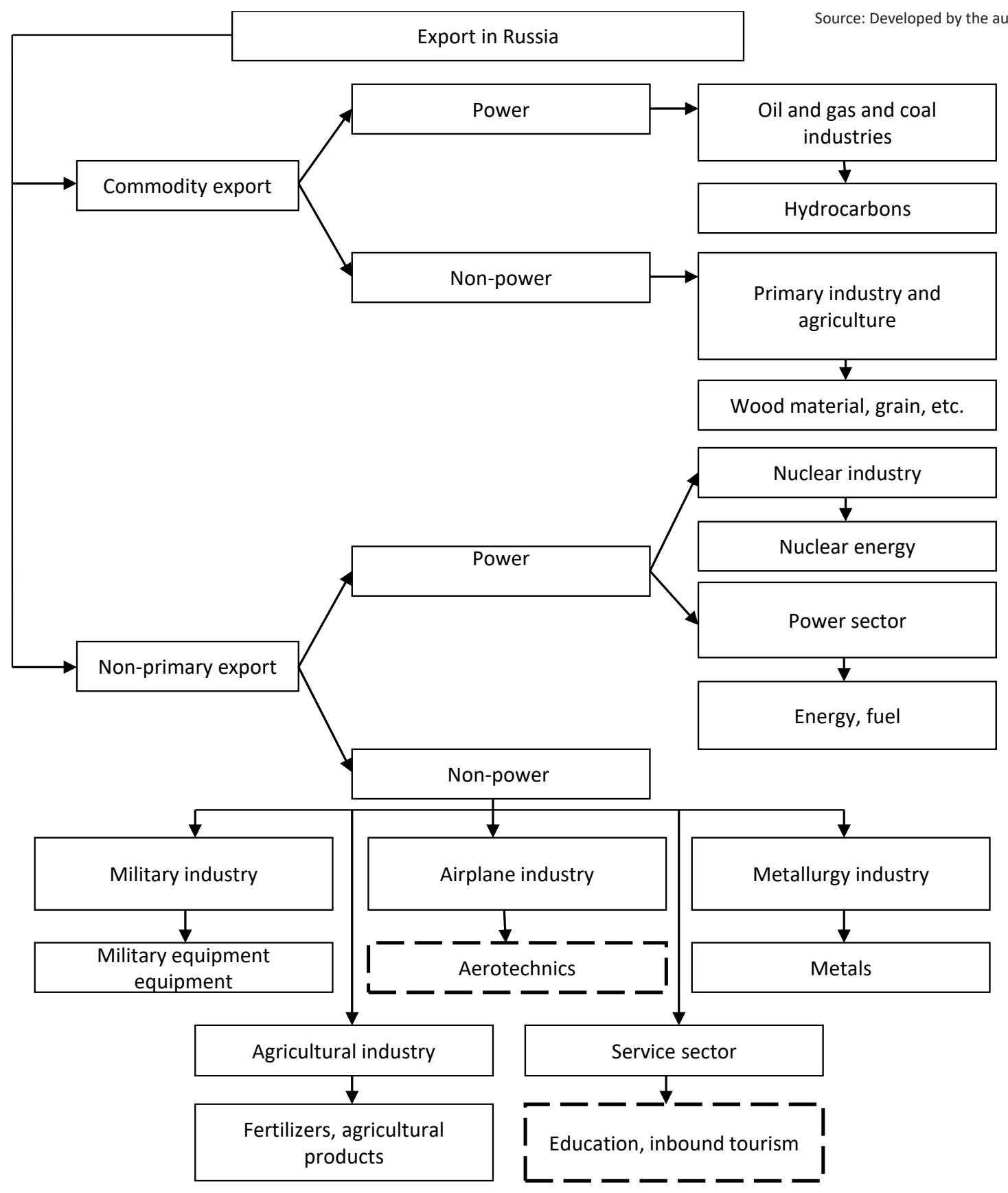

Note: Promising industries that are insufficiently developed at the moment.

Figure 1. The main existing and promising industries in Russia, manufacturing products, providing services that are exported or can be exported 
Volume of exports and imports, USD bln

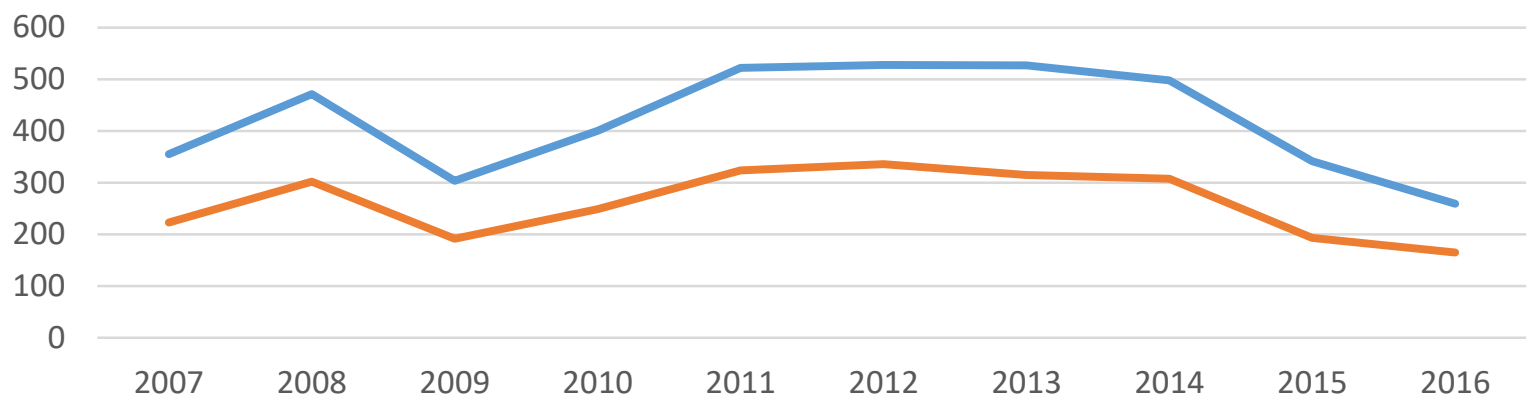

Figure 2. The volume of exports and imports of Russia in the period 2007-2016

However, according to CIA World Factbook data, in the period from 2014 to 2016, Russia's exports fell by almost half (Figure 2).

According to representatives of the Russian authorities, the growth rate of Russia's non-primary exports in 2017 reached a record level over the past ten years and amounted to $19 \%$. Sanctions affected to an extent the decline in turnover for a certain period of time, but this gave a serious impetus to Russian enterprises, which actively began to develop new projects and launch new samples of industrial products. The growth in export of non-primary products was caused not only by the ruble 2016 depreciation, but also by the reorientation of many Russian companies to foreign consumers, caused both by the policy of import substitution and state support for exports. Many foreign companies began to manufacture products on the territory of Russia and export it abroad, which is associated with a decrease in the average level of wages to a level comparable to the labor force in China (Manturov, 2017).

The agro-industrial complex, machine building and chemical industry have become growth drivers for the last year, with $8 \%$ provided by Kazakhstan, $8 \%$ by China, $7 \%$ by Belarus, and $6 \%$ by the USA. Despite the fact that $30 \%$ of non-primary exports are metal products, $20 \%$ was provided by the chemical industry, $18 \%$ by mechanical engineering, and $14 \%$ by food, Russia still delivers products that do not require high technologies for production, which does not give serious profits for exporters and often requires state support.

In Russia, a number of mechanisms (institutions, programs) are being implemented to support the development of non-primary exports, including financial (preferential loans, insurance of risks, state guarantees) (Figure 3).

The Russian Agency for Export Credit and Investment Insurance (EXIAR) and JSC Roseximbank act as agents for financial support. Since 2016, they have been merged into the REC Group (Russian Export Center), which provides targeted support to exporters of high-tech products. In particular, reimbursement of up to $80 \%$ of the total transportation costs; compensation for up to $80 \%$ of costs for participation in exhibitions; compensation of costs for the intellectual property rights protection, certification of products; financing of a foreign buyer for the acquisition of Russian high-tech products at preferential rates, etc. (Russian Export Center, 2018) are provided.

According to the priority project "International Cooperation and Export in Industry" approved by the Presidium of the Presidential Council for Strategic Development and Priority Projects in 2017, more than 6,000 exporters received assistance - the volume of subsidized loans will amount to 165 billion rubles. It is planned that by 2025 all these indicators should grow by almost half, which, accordingly, will lead to a similar increase in the non-primary exports (Shuvalov, 2017).

With that, it is not at all an unlikely scenario for the following industries to double non-primary exports in this period, and even earlier:

- agricultural machinery;

- railway engineering;

aircraft construction

automotive industry. 


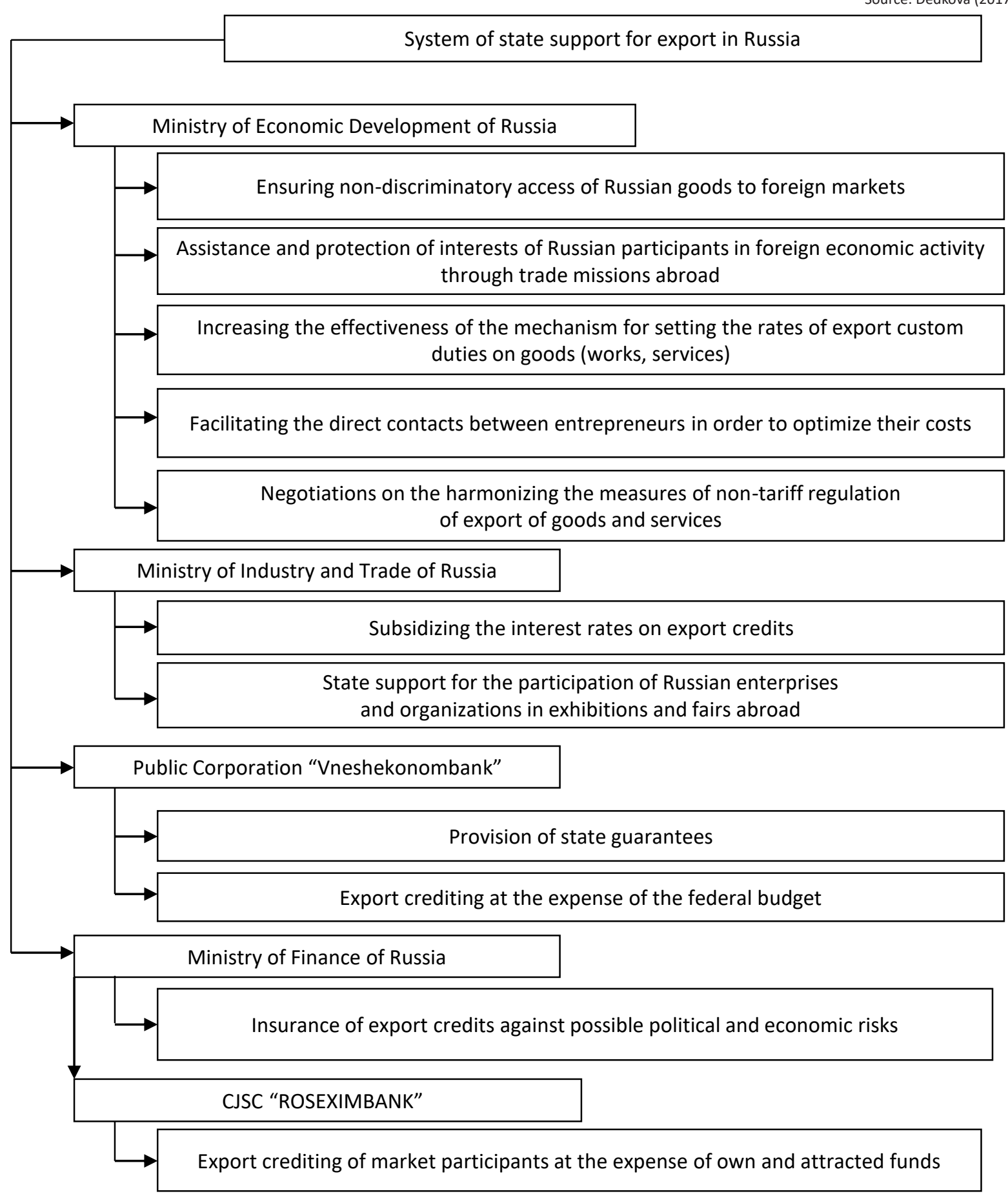

Figure 3. System of state support for export in Russia

The development of non-primary export in Russia is hampered by:

- insufficient support for the exports development by regional authorities, focused mainly on the domestic market;

- internal barriers for the development of export potential (imperfect accompanying leg- islation, undeveloped system of tax incentives and lending, poor quality management system, supply chains management, inefficient logistics system);

- external negative factors (the implementation of protectionist policies in the market by the competing countries, the physical and intellectual inability to catch up with the dynamics 
of the external market (the conditions for doing business, changing the political situation, transforming the legislation), lack of clear customs regulation and agreements between countries), etc.

The following can be the solution of the problems indicated:

- development and implementation of state support programs (federal and regional level) for export-oriented enterprises, their geographical diversification (working out a strategy for the non-primary export development in the region, the creation of an export-investment elevator, soft loans, tax preferences, a favorable investment climate for the construction of large-scale investment objects, creation of an optimal export infrastructure, a program to support the competitiveness of regional export-oriented products), which will help to remove internal barriers to export development, ensure favorable conditions for its development and expansion, consolidate the basic provisions of export activities and institutionalize it;

- strengthening the orientation towards the development and implementation of export strategies for the industries growth. The export element should be in the development strategy of each major industry, which will help to level out external negative factors through the elaboration of development aspects, the clarity of customs regulation and the availability of support measures at various stages of implementing export strategies;

- removal of internal barriers for the export potential development, including the definition of financial and information support for exports through optimization of legislation, subsidies, concessional lending, etc. (Knyazeva, 2017).

In our opinion, nowadays, the stimulation of exports in Russia also needs to focus on reducing the tax and debt burden. For non-primary exporters, it is necessary to develop an additional system of tax privileges and preferences, to improve the mechanism of customs regulation, which will help them to increase the recapitalization of profits and sales in the international market. In addition, it is necessary to pay attention to the interest rates growth of the Central Bank of the Russian Federation. Providing loans with low interest rates for exporters will help stimulate the development of economic sectors that reduce their business activity due to a lack of financial capital.

Particular attention should be paid to encouraging exports among small- and medium-sized businesses.

In Russia, currently, more than $65 \%$ of the country's total exports are in the top five of Russia's largest corporations $(85 \%$ of which are in 30 large corporations), which speaks of the export market monopolization and the underdevelopment of this area of activity in the small business sector due to its inability to compete with industry giants (Russian Export Center, 2018).

However, in many euro area countries, over 50\% of the total share of exports falls on representatives of small- and medium-sized businesses (including service providers), which indicates a high level of stimulating exports among small entrepreneurs and high representation in the international market, which is not typical for Russia.

Of particular importance in recent years is promoting the development of export industries such as inbound tourism and education. The inbound tourism's characteristic is the creation of an advanced comfortable infrastructure inside and around the traveler attractions, which allows us to talk not only about stimulating the tourism exports development, but also about the formation of favorable living and recreational conditions inside the exporting country. This sets tourism apart from other export destinations, because its development brings a twofold positive effect to the state and its population (Gudkov et al., 2017). As for education, the positive effect of the industry's development is also increasing, new jobs are being created in the country, the provision of educational services, in view of its specifics, creates an additional demand for domestic products from foreign persons forced to reside outside their place of permanent residence. Thus, we believe that in the export of services, the greatest attention should be paid to the development of the education and tourism as inexhaustible and highly profitable sources that have proved their priority in the world space. 
Table 1. Differentiation of enterprises engaged in non-primary export

Source: Compiled by the authors.

\begin{tabular}{|c|c|c|}
\hline Sector profile & Share of export & Brief description of incentive measures applied \\
\hline \multirow{4}{*}{$\begin{array}{l}\text { Production sphere } \\
\text { (export of goods) }\end{array}$} & $\begin{array}{l}\text { Up to } 25 \% \text { of total } \\
\text { revenue }\end{array}$ & Organizational and consulting support for enterprises \\
\hline & $\begin{array}{l}\text { From } 25 \text { to } 50 \% \text { of } \\
\text { total revenue }\end{array}$ & Information support for enterprises; tax incentives - application of tax incentives \\
\hline & $\begin{array}{l}\text { From } 50 \text { to } 75 \% \text { of } \\
\text { total revenue }\end{array}$ & $\begin{array}{l}\text { Information support for enterprises; tax incentives - application of tax incentives; } \\
\text { customs regulation - reduction of customs expenses }\end{array}$ \\
\hline & $\begin{array}{l}\text { Over } 75 \% \text { of total } \\
\text { revenue }\end{array}$ & $\begin{array}{l}\text { Information support for enterprises; tax incentives - application of tax incentives } \\
\text { and special taxation regime; minimization of customs expenses }\end{array}$ \\
\hline \multirow{4}{*}{$\begin{array}{l}\text { Services (export of } \\
\text { services and works) }\end{array}$} & $\begin{array}{l}\text { Up to } 25 \% \text { of total } \\
\text { revenue }\end{array}$ & $\begin{array}{l}\text { Organizational, consulting and information support for enterprises; tax incentives } \\
- \text { application of tax incentives }\end{array}$ \\
\hline & $\begin{array}{l}\text { From } 25 \text { to } 50 \% \text { of } \\
\text { total revenue }\end{array}$ & $\begin{array}{l}\text { Information support for enterprises; tax incentives - application of tax incentives; } \\
\text { state export subsidies }\end{array}$ \\
\hline & $\begin{array}{l}\text { From } 50 \text { to } 75 \% \text { of } \\
\text { total revenue }\end{array}$ & $\begin{array}{l}\text { Information support for enterprises; tax incentives - application of tax incentives } \\
\text { and special taxation regime; customs regulation - reduction of customs expenses; } \\
\text { state export subsidies }\end{array}$ \\
\hline & $\begin{array}{l}\text { Over } 75 \% \text { of total } \\
\text { revenue }\end{array}$ & $\begin{array}{l}\text { Information support of enterprises; tax incentives - the application of tax } \\
\text { incentives and a special taxation regime; minimization of customs expenses }\end{array}$ \\
\hline
\end{tabular}

It is essential to ensure the industries' growth through specialized stimulating measures; to change the system of customs and tax benefits in terms of their recipients, the terms of delivery and the types of goods for which they are provided. High customs payments for export should be redistributed for the modernization and construction of processing industry facilities.

It is also necessary to study the possibilities of stimulating the use of industrial equipment for the manufacturing export products through a reduction in the property tax rate or through partial compensation by reducing other mandatory payments.

It should be noted that the measures of tax incentives should be applied to a greater extent only to enterprises whose activities are directed primarily at the export of manufactured goods, works and services. In this case, it seems expedient to divide export organizations into several categories according to the volume of export products (Table 1).

As can be seen from Table 1, at the initial stage of the development of an integrated system for stimulating non-primary export, it is planned to support the services sector to a greater extent. This is due to the fact that until now the services have not received due attention from the state as to enhancing their export activities. Elimination of this discrepancy requires serious intervention through the implementation of pushing mechanisms and incentive measures at the very first stage of export op- portunities (when exports account for up to $25 \%$ of total revenue). In addition, since services are often provided within the country, it will be quite appropriate to apply not only tax and customs incentive mechanisms, but also direct government subsidies for exports, with the possibility of working out additional programs for budget financing and co-financing of nationally important projects.

However, both for services and for the production sector at the current stage, the most important is the legislative consolidation of the fiscal and tax policies of the state as the most important effective mechanism for the long-term regulation of industries.

Thus, in order to ensure Russia's economic and food security, it is possible to propose the following basic measures of tax incentives for exports, which, according to the authors, are the primary directions for implementing the state policy to increase non-primary exports (Table 2).

These measures are proposed by the authors with the elaboration of not only a specific idea for implementation, but also the definition of a normative document requiring adjustment, the RF agency responsible for making changes in accordance with the powers given to it, as well as the potential risks when using the proposed direction of tax incentives for exports and the expected positive results of implementation provided that risks are avoided or minimized. Clear regulation of the proposed incentive measures is due to the current 
Table 2. Proposed measures of tax incentives for non-primary export in Russia

Source: Compiled by the authors.

\begin{tabular}{|c|c|c|c|c|}
\hline No. & $\begin{array}{l}\text { The normative legal } \\
\text { act to which the } \\
\text { amendment is made }\end{array}$ & $\begin{array}{l}\text { The body in charge } \\
\text { of the issue }\end{array}$ & Possible risks & Expected results \\
\hline & \multicolumn{4}{|c|}{$\begin{array}{l}\text { Full exemption of exporters from VAT payment through the introduction of a tax credit system for VAT. When using the } \\
\text { system of tax credit for VAT exporters, all registered exporting enterprises receive a tax credit in the amount of VAT paid } \\
\text { by them for purchases on the domestic market. At the end of each reporting period, exporters summarize the total amount } \\
\text { of VAT paid and deduct this amount from the total amount of tax payments for this reporting period }\end{array}$} \\
\hline 1 & $\begin{array}{l}\text { Chapter } 21 \text { of the Tax } \\
\text { Code of the RF } \\
\text { Methodological } \\
\text { recommendations } \\
\text { on the application of } \\
\text { Chapter } 21 \text { of the Tax } \\
\text { Code of the RF }\end{array}$ & $\begin{array}{l}\text { Ministry of Finance of } \\
\text { the RF } \\
\text { Federal Tax Service } \\
\text { of RF }\end{array}$ & $\begin{array}{l}\text { The decrease in the } \\
\text { revenues of the RF } \\
\text { budget from VAT. Risks of } \\
\text { errors in the calculation } \\
\text { of VAT (the need for } \\
\text { separate accounting for } \\
\text { exports of goods, works } \\
\text { and services and those } \\
\text { for the domestic market) }\end{array}$ & $\begin{array}{l}\text { The system in question completely excludes } \\
\text { VAT from the export cost of goods (works } \\
\text { and services), stimulates the flow of } \\
\text { investment and supports the competitiveness } \\
\text { of exporters }\end{array}$ \\
\hline & \multicolumn{4}{|c|}{$\begin{array}{l}\text { Shaping a system of advanced tax credit for VAT. When using this tool, the VAT tax credit is envisaged to be extended } \\
\text { in the new reporting year in relation to advance payments for all taxes paid based on the volume of the VAT tax credit } \\
\text { received for the previous reporting tax period. At the end of the new reporting period, the tax credit for VAT is calculated } \\
\text { for the new period and when it is reduced relative to the amounts already used, additional payments are made to the RF } \\
\text { budget as a result of failure to make advance payments for various taxes }\end{array}$} \\
\hline 2 & $\begin{array}{l}\text { Chapter } 21 \text { of the Tax } \\
\text { Code of the RF } \\
\text { Methodological } \\
\text { recommendations } \\
\text { on the application of } \\
\text { Chapter } 21 \text { of the RF } \\
\text { Tax Code }\end{array}$ & $\begin{array}{l}\text { Ministry of Finance of } \\
\text { the RF } \\
\text { Federal Tax Service of } \\
\text { the RF }\end{array}$ & $\begin{array}{l}\text { The decrease in the } \\
\text { revenues of the RF } \\
\text { budget from VAT. } \\
\text { The availability of a } \\
\text { temporary lag on the } \\
\text { receipt of taxes and fees } \\
\text { by the budget. Risks of } \\
\text { errors in the calculation } \\
\text { of VAT (the need for } \\
\text { separate accounting } \\
\text { for exports of goods, } \\
\text { works and services and } \\
\text { those for the domestic } \\
\text { market). The risk of } \\
\text { inefficiency of the new } \\
\text { tax regime (problems of } \\
\text { tax administration and } \\
\text { negative effect for the } \\
\text { state) }\end{array}$ & $\begin{array}{l}\text { The proposed measure maximally excludes } \\
\text { the time gap between the actual payment } \\
\text { of VAT by the exporter and its refund, } \\
\text { minimizing the impact on the enterprise's } \\
\text { financial position. There is no diversion of } \\
\text { the circulating assets of the exporter and, as a } \\
\text { consequence, a slowdown in the production } \\
\text { cycle }\end{array}$ \\
\hline
\end{tabular}

Transformation of the procedure for VAT implementation on goods imported into the country from abroad. The time shift for the VAT implementation from the time of customs clearance at the moment the final product of the exporting enterprise is sold. If the sale is carried out on the external market, the payment of VAT, and therefore its subsequent refund, is not required

\section{Chapter 21 of the Tax}

3 Code of the RF

Methodological recommendations on the application of Chapter 21 of the RF Tax Code
The decrease in the revenues of the RF budget from VAT. Risks of errors in the calculation of VAT (the need for

Ministry of Finance of separate accounting for exports of goods, works The volume of tax credits and the number $\begin{array}{ll}\text { the RF } & \text { exports of goods, work } \\ \text { and services and those }\end{array}$ Federal Tax Service of for the domestic market). the RF of the new tax regime (problems of tax administration and the possibility of fraud on the part of exporters) of claims for VAT refund are significantly reduced. The work of tax services is being optimized

Replacement of monetary compensation of VAT to exporters for tax certificates, which can pay any taxes and fees levied from the organization. It is actual in case if the tax credit by VAT for the reporting period exceeded the aggregate of other accrued taxes and is transferred to the future tax period

4

Chapter 21 of the Tax

Code of the RF

Methodological recommendations on the application of Chapter 21 of the RF Tax Code
Ministry of Finance of

the RF

Federal Tax Service of

the RF 
Table 2 (cont.). Proposed measures of tax incentives for non-primary export in Russia

\begin{tabular}{|c|c|c|c|c|}
\hline No. & $\begin{array}{l}\text { The normative legal } \\
\text { act to which the } \\
\text { amendment is made }\end{array}$ & $\begin{array}{l}\text { The body in charge } \\
\text { of the issue }\end{array}$ & Possible risks & Expected results \\
\hline \multirow[b]{2}{*}{5} & \multicolumn{4}{|c|}{$\begin{array}{l}\text { Exemption from property tax of organizations, land tax of enterprises with a share of exports in the amount of revenue of } \\
\text { more than } 50 \% \text { for a period of up to } 10 \text { years from the date of their state registration and reliable confirmation of the share } \\
\text { of exports for the first reporting year }\end{array}$} \\
\hline & $\begin{array}{l}\text { Charters } 30 \text { and } 31 \text { of } \\
\text { the Tax Code of the RF } \\
\text { Tax laws of the } \\
\text { entities of the Russian } \\
\text { Federation (corporate } \\
\text { property tax) } \\
\\
\text { Tax normative legal } \\
\text { acts of representative } \\
\text { bodies of municipal } \\
\text { entities taxes (land tax) }\end{array}$ & $\begin{array}{l}\text { Ministry of Finance of } \\
\text { the RF } \\
\text { Federal Tax Service of } \\
\text { the RF } \\
\text { Executive authorities } \\
\text { of the subjects of } \\
\text { the RF } \\
\text { Local government } \\
\text { bodies }\end{array}$ & $\begin{array}{l}\text { Significant costs for } \\
\text { the implementation } \\
\text { of the tax mechanism } \\
\text { and subsequent tax } \\
\text { administration. The risk } \\
\text { of continued payback } \\
\text { and the possibility of } \\
\text { misuse of property and } \\
\text { land by exporters }\end{array}$ & $\begin{array}{l}\text { Stimulation of production expansion, fixed } \\
\text { assets renewal, increase of competitiveness. } \\
\text { Reduction of tax burden }\end{array}$ \\
\hline \multirow[b]{2}{*}{6} & \multicolumn{4}{|c|}{$\begin{array}{l}50 \% \text { reduction of transport tax rates established in the region in relation to vehicles manufactured in Russia used for } \\
\text { export activities }\end{array}$} \\
\hline & $\begin{array}{l}\text { Chapter } 28 \text { of the Tax } \\
\text { Code of the RF } \\
\text { Tax laws of the } \\
\text { entities of the Russian } \\
\text { Federation (transport } \\
\text { tax) }\end{array}$ & $\begin{array}{l}\text { Ministry of Finance of } \\
\text { the RF } \\
\text { Federal Tax Service of } \\
\text { the RF } \\
\text { Executive authorities } \\
\text { of the RF entities }\end{array}$ & $\begin{array}{l}\text { Significant costs for } \\
\text { the implementation } \\
\text { of the tax mechanism } \\
\text { and subsequent tax } \\
\text { administration. The risk } \\
\text { of continued payback } \\
\text { and the possibility of } \\
\text { misuse of vehicles }\end{array}$ & $\begin{array}{l}\text { Stimulation of the domestic vehicles use. } \\
\text { Reduction of the tax burden for transport tax }\end{array}$ \\
\hline \multirow[b]{2}{*}{7} & \multicolumn{4}{|c|}{$\begin{array}{l}\text { Lowering of tariffs of insurance premiums for exporting payers with a share of exports in the amount of revenue of more } \\
\text { than } 50 \% \text { from the moment of confirming the export share for the first reporting year. The rates for compulsory pension } \\
\text { insurance are } 13 \% \text { in } 2019-2020,17 \% \text { in } 2021-2022 \text {, and } 21 \% \text { in } 2023-2024 \text {. The rate for compulsory social insurance in } \\
\text { case of temporary incapacity for work and due to maternity is } 2.0 \% \text {. The rate for compulsory medical insurance is } 4.0 \%\end{array}$} \\
\hline & $\begin{array}{l}\text { Chapter } 34 \text { of the Tax } \\
\text { code of the RF }\end{array}$ & $\begin{array}{l}\text { Ministry of Finance of } \\
\text { the RF } \\
\text { Federal Tax Service of } \\
\text { the RF }\end{array}$ & $\begin{array}{l}\text { Decrease in incomes of } \\
\text { off-budget funds of the } \\
\text { Russian Federation. Risk } \\
\text { of continued payback }\end{array}$ & $\begin{array}{l}\text { Encouraging the establishment of real wage } \\
\text { levels and raising the level of personal } \\
\text { income tax paid. Skilled workers intake. } \\
\text { Reduction of tax burden on insurance } \\
\text { premiums }\end{array}$ \\
\hline
\end{tabular}

system of Russian tax legislation, which accumulates all applicable taxes, fees and insurance fees on the territory of the Russian Federation in a single codified legislative act - the Tax Code of the Russian Federation.

The implementation of the designated authorial measures of tax incentives for non-primary exports of Russia is assumed to have the following positive financial effects:

- for exporting enterprises - in terms of the release of additional funds (mainly because of savings on taxes caused by a reduction in the tax burden), which can be used to develop new sales markets, expand the range of products, introduce innovative production technologies, etc. (a positive effect will be achieved already in the first years of the transformation of tax legislation); for the state - in terms of additional tax revenues to the budget associated with an increase in the number of taxpayers and the growth of the aggregate tax base (tax incentives will stimulate enterprises to develop export activities, intensify export activities) as well as foreign investors intake. With that, it is necessary to note the inevitable presence of a fiscal lag for budget revenues in the first years of introducing tax incentives due to a significant decrease in tax rates and a temporal absence of growth in the tax base. However, the gradual adaptation of the business to new more comfortable and loyal tax conditions for export activities will eventually result in a tax revenue increase of the budget and the formation of a more stable diversified structure of the state economy. 


\section{CONCLUSION}

It can be summarized that the support of domestic non-primary export is a matter of Russia's strategic development. Non-primary export growth depends on the following conditions:

- development of trade and economic relations aimed at promoting domestic products to world markets;

- increasing the effective Russia's participation in the world trading system;

- use of export support mechanisms;

- intensive development of transport and logistics infrastructure (Arskiy, 2015);

- shaping the favorable socio-economic environment within the country, aimed at creating a favorable conjuncture in relation to people and economic entities, and free from political influence;

- simplification and acceleration of customs procedures for participants of foreign economic activities (Oganisian, 2017).

However, imperfect tax legislation often negates all positive development conditions, that is why, this article has paid more attention to the proposal of the system of tax incentive measures as the primary driver of non-primary exports development.

Given the analysis carried out in Russia, there is the objective necessity of the most intensive support for the following promising export industries:

- inbound tourism;

- $\quad$ automotive and aviation industry;

- education.

It is these sectors that can be characterized as the most stable in the context of the world economy transformation. The proposed incentive measures just take into account the orientation to such industries, but can be further explored in the future to form an expanded set of organizational and financial mechanisms for optimal impact in order to more fully meet the objectives and achieve the results planned.

Thus, the development of non-primary exports in Russia will not only reduce the dependence of the economy on the inevitably cheaper and less demanded hydrocarbons, but also achieve a multiplicative effect: increase the labor employment of the population, increase the pace of the country's infrastructure development, provide the budget with high incomes, even under internal inflation, which ultimately leads to an improvement in the standard of living of citizens and the strengthening of the country's economic sovereignty.

\section{ACKNOWLEDGEMENT}

The article was prepared within the framework of the President of the Russian Federation grant for the state support of young Russian scientists - Ph.D. MK-404.2018.6 "Tax incentives of non-primary export in Russia".

\section{REFERENCES}

1. Arskiy, A. A. (2015).

Информационная логистика

во внешнеэкономической деятельности [Informatsionnaya logistika vo vneshneekonomicheskoy deyatelnosti]. Mir Sovremennoy Nauki, 3, 48-51.
2. Brown, L. K. (2018). A re-analysis of the trade and welfare effects of export subsidies. Applied Economics Letters, 25(6), 420-424.

3. Byrkova, Е. (2017). Внешняя торговля России в 2016 году: цифры и факты [Vneshniaya torgovlia
Rossii v 2016 godu: tsifry i fakty]. Retrieved from http://провэд.рф/ analytics/research/40407-vneshnyaya-topgovlya-possii-v-2016-godu-tsifpy-i-fakty.html

4. Dedkova, E. G. (2017). Несырьевой экспорт в России: 
современное состояние и перспективы развития [Nesyryevoy eksport v Rossii: sovremennoye sostoyaniye i perspektivy razvitiya]. Ekonomicheskiye i Gumanitarnyye Nauki, 9, 101-108.

5. Dumnaya, N. N., Kolodniaya, G. V., \& Yudanov, A. Yu. (2015). Средний бизнес и проблемы российского несырьевого экспорта [Sredniy bizness i problem rossiyskogo nesyryevogo eksporta]. Menedzhment: Laboratoriya Sovremennykh Praktik 3, 66-74.

6. Fujii, D., Ono, Y., \& Saito, Y. U. (2017). Indirect exports and wholesalers: Evidence from interfirm transaction network data. Japan and the World Economy, 44, 35-47.

7. Gudkov, A., Dedkova, E., \& Dudina, K. (2017). Tax incentives as a factor of effective development of domestic tourism industry in Russia. Problems and Perspectives in Management, 15(2), 90-101. https://doi.org/10.21511/ ppm.15(2).2017.09

8. Hjerpe, E. E. (2018). Outdoor Recreation as a Sustainable Export Industry: A Case Study of the Boundary Waters Wilderness. Ecological Economics, 146, 60-68.

9. Investing.com (2018). Сальдо торгового баланса России [Saldo torgovogo balansa Rossii]. Retrieved from https://ru.investing.com/ economic-calendar/russian-tradebalance- 550

10. Kadochnikov, S., \& Fedyunina, A. (2017). The impact of foreign direct investment on export activity of Russian Firms: The size matters. Voprosy Ekonomiki, 12, 96-119.

11. Kalafsky, R. V., \& Graves, W. (2017). Exports and Growth: Learning from the Case of Southern U.S. Metropolitan Areas. Professional Geographer, 1-12.

12. Kaliappan, S. R., Ahmad, S. A., \& Ismail, N. W. (2017). Service export and economic growth in the selected developing Asian countries. International Journal of Economics and Management, 11(2), 393-418.

13. Kiendrebeogo, Y., \& Minea, A. (2017). Financial Factors and
Manufacturing Exports: FirmLevel Evidence from Egypt. Journal of Development Studies, 53(12), 2197-2213.

14. Knyazeva, O. N. (2017). Стимулирование экспорта в России. Молодежный научный борум: Обшественные и экономические науки [Stimulirovaniye eksporta $v$ Rossii. Molodiozhnyy nauchnyy forum: obshchestvennyye i ekonomicheskiye nauki]. Retrieved from https://nauchforum. ru/archive/MNF_social/4(44).pdf

15. Krammer, S. M., Strange, R., \& Lashitew, A. (2018). The export performance of emerging economy firms: The influence of firm capabilities and institutional environments. International Business Review, 27(1), 218-230.

16. Laumas, P. S. (1982). Exports and the propensity to save. Economic Development and Cultural Change, 30(4), 831-841.

17. Lianling, Y., \& Cuihong, Y. (2017) Changes in domestic value added in China's exports: a structural decomposition analysis approach. Journal of Economic Structures, 6(1), 18.

18. Manturov, D. (2017). Не небтьюю единой: Россия резко увеличила объем несьрьевого экспорта [Ne neftyu yedinoy: Rossiya rezko uvelichila obyem nesyryevogo eksporta]. Retrieved from http:// geo-politica.info/ne-neftyu-edinoyrossiya-rezko-uvelichila-obemnesyrevogo-eksporta.html

19. Oganisian, G. O. (2017). Механизмы стимулирования экспортной деятельности [Mekhanizmy stimulirovaniya eksportnoy deyatelnosti]. Problemy Ekonomiki i Yuridicheskoy Praktiki, 4, 39-41.

20. Rangasamy, L. (2009). Exports and economic growth: The case of South Africa. Journal of Interna tional Development, 21(5), 603-617.

21. Rementsov, A. N. (2015). Направления экспорта образовательных услуг в вузе [Napravleniya eksporta obrazovatelnykh uslug v vuze]. Vyssheye Obrazovaniye v Rossii, 11, 119-126.
22. Russian Export Center (2018). Retrieved from https://www.exportcenter.ru/

23. Shuvalov, I. (2017).

Приоритетный проект

"Международная кооперация и экспорт в промышленности" (“Экспорт в промьишенности”)

[Prioritetnyy proekt "Mezhdunarodnaya kooperatsiya i eksport v promyshlennosti" ("Eksport v promyshlennosti”)]. Retrieved from http://government.ru/projects/ selection/651/

24. Shuyskiy, V. P. (2012).

Совершенствование системы поддержки экспорта в России [Sovershenstvovaniye sistemy podderzhki eksporta v Rossii]. Rossiyskiy Vneshneekonomicheskiy Vestnik, 9, 35-48.

25. Suri, F. K., \& Banerji, A. (2017). Exports Cause Outward Foreign Direct Investment in Indian Pharmaceutical Industry? Journal of Health Management, 19(4), 584-601.

26. Susanian, K. G. (2010). Формы государственной поддержки российского экспорта [Formy gosudarstvennoy podderzhki rossiyskogo eksporta]. Rossiyskiy Vneshneekonomicheskiy Vestnik, 8, 39-47.

27. Tashlykov, A. М. (2007). Экспорт образовательных услуг [Eksport obrazovatelnykh uslug]. Nauchnyy Vestnik MGTU GA, seriya Mezhdunarodnaya deyatelnost vuzov, 116, 150-152.

28. Unal, E. (2018). An institutional approach and input-output analysis for explaining the transformation of the Turkish economy. Journal of Economic Structures, 7(3).

29. Vasiutchenko, I. N. (2010). Государственная поддержка экспорта: мировой опыт [Gosudarstvennaya podderzhka eksporta: mirovoy opyt]. TerraEconomicus, 1(3), 243-250

30. Yusupova, A., \& Khalimova, S. (2017). Characteristics, features of development, regional and sectoral determinants of high-tech business in Russia. Voprosy Ekonomiki, 12, 142-154. 